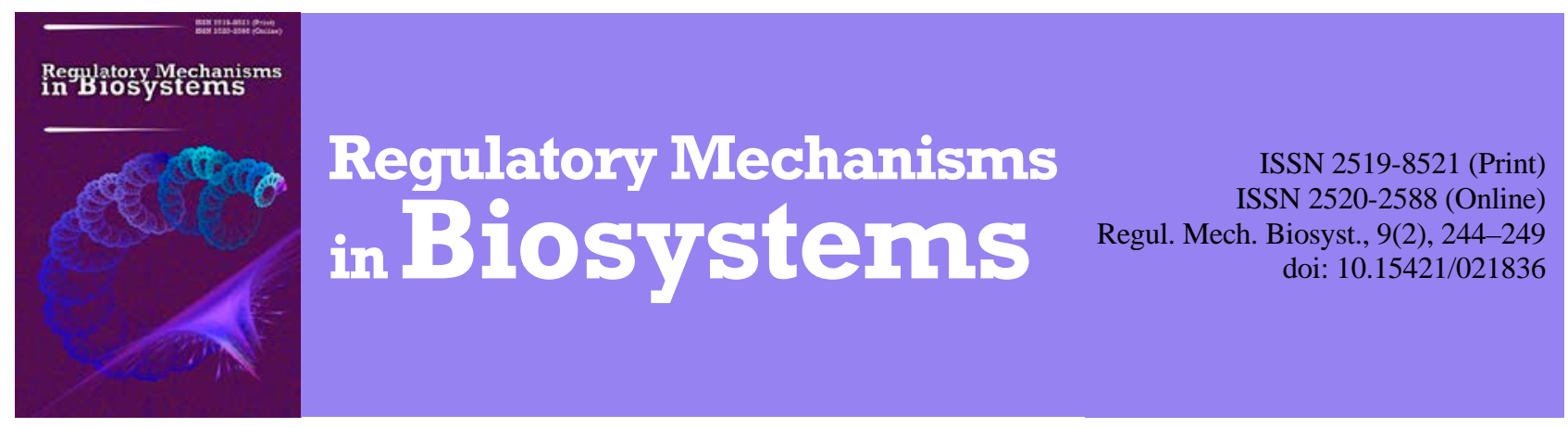

\title{
Biochemical and hematological composition of blood of cattle fed with Chlorella
}

\author{
A. A. Bogdanova*, E. A. Flerova*,** \\ *Yaroslavl Research Institute of Livestock and Fodder Production - Affiliate of "FWRC FPA", Yaroslavl Oblast, Russia \\ **The Yaroslavl Demidov State University, Yaroslavl, Russia
}

Article info

Received 27.03.2018

Received in revised form 22.04.2018

Accepted 25.04.2018

Yaroslavl Research Institute of Livestock and Fodder Production Affiliate of "FWRC FPA",

Mikhailovsky village, 150517

Yaroslavl Oblast, Yaroslavsky

District, Russia.

E-mail:

bogdanova.ale@gmail.com

The Yaroslavl Demidov

State University,

Yaroslavl, 150003, Russia.

\begin{abstract}
Bogdanova, A. A., \& Flerova, E. A. (2018). Biochemical and hematological composition of blood of cattle fed with Chlorella. Regulatory Mechanisms in Biosystems, 9(2), 244-249. doi:10.15421/021836
\end{abstract}

We researched the influence of the additive Chlorella cultivated in a closed bioreactor under the influence of an electrostatistic field, on the biochemical and hematological parameters of blood in different age groups of cattle. The experiment was conducted on two groups of three month old heifers and two groups of lactating cows in the 7th month of lactation, with 15 individuals in each group; all animals in the groups were given the basic diet. During the 120-day experiment, the experimental group of heifers was fed on a suspension of Chlorella cultivated with the technology using an electrostatic field, in the following amounts: 1-30th day - 1.51 g, 31-60th day - 1.82 g, 61-90th day - 2.01 g, 91-120th day $-2.28 \mathrm{~g}$ of dry substance per individual daily; the group of lactating cows during 60 days was given the Chlorella additive to the amount of $6 \mathrm{~g}$ of dry substance per individual per day. Over the following 30 days the heifers and lactating cows were kept under observation to determine the "aftereffects" of the Chlorella suspension fodder additive. On the first day of the experiment and after every 30 days, blood was drawn from the animals' jugular veins for determination of the biochemical and hematological parameters of the blood During the experiment, the experimental groups of heifers and lactating cows were observed to have a strengthened antioxidant system due to increase in the activity of superoxide dismutase and catalase, and also to have a strengthened hematopoietic function and intensified metabolic and redox processes. Due to the stimulating effect of the suspension of Chlorella cultivated using the intense technology involving using an electrostatic field on the erythro- and leukopoiesis of different age groups of the cattle, we determined a strengthening of the cellular element of the animals' immune system. During the following 30 days, the heifers and lactating cows of the experimental groups were observed to exhibit "aftereffects" of the Chlorella suspension additive, namely increases in the values of biochemical, hematological and morphological indicators of the blood in comparison with these indicators for the animals in the control groups. As a result, we concluded that feeding different age groups of cattle with suspension of Chlorella cultivated in the conditions of a closed bioreactor under the influence of an electrostatic field, in the dosage of $155 \mathrm{ml}$ per kg of dry substance of the animals' diet, contributes to the strengthening of non-specific defence of their organism, forming a potential for increasing the productive indicators and maintenance of the livestock.

\section{Introduction}

A promising method of improving the efficiency of the indicators of productivity of agricultural livestock is improving their digestion of fodder, which is achieved through adding a broad spectrum of highly biologically active micro-nutrients. It is known that the natural food additives made of algae possess a broad spectrum of biologically active substances with high biological accessibility for the organism of cattle. One such additive is suspension of Chlorella. The latter is one of the most widely cultivated eukaryotic green microalgae and is grown to be used as an additive to the food of animals and humans, and is also used in the pharmaceutical and cosmetological industries all around the world, especially in Asian countries, such as Japan, Taiwan, and Korea (Ogbonna, 1997; Lee, 2001; Pulz \& Gross, 2004; Becker, 2006; Spolaore, 2006; Bishop \& Zubeck, 2012; Lum et al., 2013; Guccione, 2014; Costa et al., 2016).

In the conditions of optimum growth, the biomass of Chlorella consists $25-50 \%$ of protein, 5-35\% of carbohydrates and 5-20\% of fat which is present as non-saturated fatty acids, the greater part of which is stearic, oleic, arachidonic, linolenic and linoleic acids, 5$10 \%$ of mineral substances, mostly consisting of phosphorus, sulfur and magnesium, and also carotene, vitamins $\mathrm{C}$ and $\mathrm{K}$ and vitamins of group B (Panahi et al., 2015). The microalgae contains peptides, alkaloids, polysaccharides, which can be used as both antimicrobial and antibacterial substances, and likewise, Chlorella has antioxidant properties, for it contains antioxidant enzymes, such as superoxide dismutase and catalase (Shibata et al., 2003; Lee et al., 2010; Aliahmat et al., 2012; Zheng et al., 2012; Flerova \& Bogdanova, 2014).

The most economically efficient biotechnological solution is cultivating Chlorella microalgae in devices of an open type, but in territories of mild climatic zones with constantly changing weather conditions, this method is impossible to implement (Borowitzka, 1999; Carvalho et al., 2006; Del Campo et al., 2007; Christaki et al., 2011; Huo, 2012). To solve this problem, a technology was developed to cultivate Chlorella in conditions of a closed type bioreactor using the stimulating effect of an electrostatic field, which allows a large amount of biomass to be obtained on small areas at low cost and with no loss of the algae's nutritional values and fodder qualities necessary for improving the productivity and maintenance of livestock. This technology allows a suspension of Chlorella to be obtained with a density of no less than $50 \mathrm{M}$ cells per a ml every 48 hours (Flerova \& Bogdanova, 2014; Schmigel et al., 2015a, 2015b).

The effect of suspension of Chlorella grown using the developed technology on the organism of cattle remains an open question. The study of this issue is impossible without analyzing the biochemi- 
cal composition and hematological parameters of the blood, which characterize the functional condition of an organism.

The objective of this study was the analysis of biochemical and hematological blood parameters of different age groups of Yaroslavl breed cattle following addition of a suspension of Chlorella cultivated in an electrostatic field to their main diet.

\section{Materials and methods}

The studies were carried out on the premises of "Mologa" Ltd. in Yaroslavl Oblast on heifers and lactating cows of Yaroslavl breed of cattle. The animals for experiments were selected using the principle of analogous pairs in accordance with standard methodological recommendations, taking into account breed, age, average live body weight, origin, average daily growth among heifers, and average daily milk yield of lactating cows (Table 1) (Viktorov \& Menkin, 1991). Throughout the experiment, the heifers and cows of the control and experi-

\section{Table 1}

Characteristics of experimental groups of Yaroslavl breed cows mental groups received a daily food diet of nutritional value which equaled the norm for animals of a corresponding age (Makartsev, 2012).

Apart from the main daily diet, the animals of the experimental groups in "Mologa" Ltd. were fed with Chlorella suspension. These microalgae were cultivated in the conditions of a closed bioreactor under the influence of an electrostatic field of $15 \mathrm{kV}$ pressure (Schmigel et al., 2015a; Schmigel et al., 2015b). This bioreactor is a device for cultivating Chlorella, which consists of 2 aquariums on a metal frame (in the upper aquarium, the water is held and a growth medium is prepared; in the lower aquarium, the Chlorella grows), two reservoirs, in this case barrels, were placed on a frame for maintenance of the prepared Chlorella suspension and a control unit for automizing the process of Chlorella suspension cultivation. The stimulation of Chlorella suspension by electrostatic field was carried out using a system of electrodes fixed on the parallel walls of the reservoirs. The electrodes were applied to the source of constant electric current, which was placed in the control unit (Fig. 1).

\begin{tabular}{|c|c|c|c|c|}
\hline \multirow{2}{*}{ Indicators } & \multicolumn{2}{|c|}{ Heifers } & \multicolumn{2}{|c|}{ Lactating cows } \\
\hline & control & experimental & control & experimental \\
\hline Number of animals, ind. & 15 & 15 & 15 & 15 \\
\hline Average live body weight, $\mathrm{kg}$ & $68.3 \pm 3.5$ & $69.7 \pm 4.1$ & $480 \pm 21.7$ & $499 \pm 23.4$ \\
\hline Average daily growth, $\mathrm{g}$ & $567 \pm 23.7$ & $560 \pm 25.1$ & - & - \\
\hline Age group & \multicolumn{2}{|c|}{ heifers below one year } & \multicolumn{2}{|c|}{ first heifers } \\
\hline Origin & \multirow{2}{*}{\multicolumn{2}{|c|}{$\begin{array}{c}\text { Dobry line } \\
1^{\text {st }} \text { to } 6^{\text {th }} \text { month- }- \text { oroun. } 6^{\text {th }} \text { month }- \text { tie bousing }\end{array}$}} & \multirow{2}{*}{\multicolumn{2}{|c|}{$\begin{array}{l}\text { Dobry line } \\
\text { tie housing }\end{array}$}} \\
\hline Maintenance & & & & \\
\hline Average daily milk yield of natural milk during 100 days of lactation, kg & \multicolumn{2}{|c|}{-} & $24.38 \pm 1.18$ & $24.53 \pm 0.92$ \\
\hline Average daily yield of $4 \%$ milk during 100 days of lactation, $\mathrm{kg}$ & \multicolumn{2}{|c|}{ - } & $24.56 \pm 1.19$ & $24.86 \pm 0.93$ \\
\hline
\end{tabular}

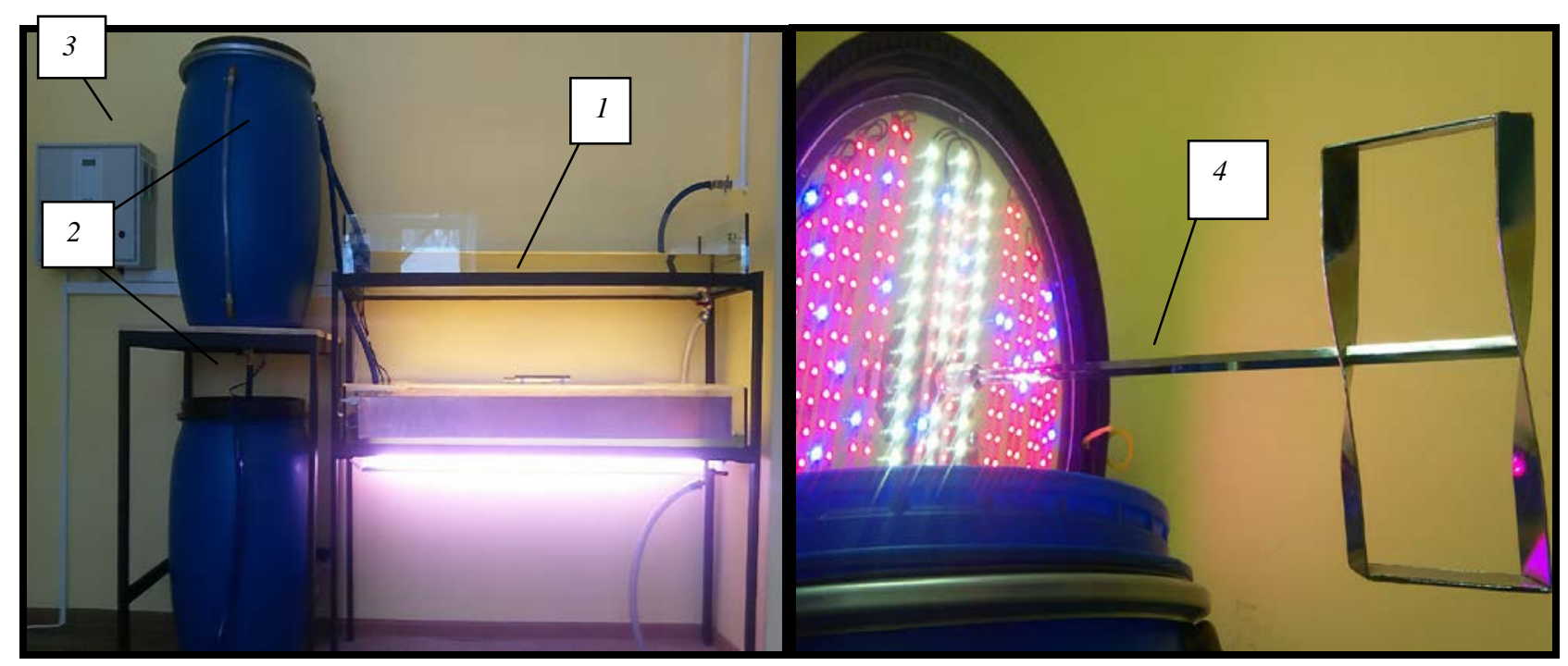

Fig. 1. Bioreactor for cultivating Chlorella in an electrostatic field: 1 - device for cultivating Chlorella in an electrostatic field; 2 - barrels for maintaining the prepared suspension of Chlorella; 3 - control unit with a source of constant electrostatic field and automatization of the process of cultivating Chlorella suspension; 4 - cover of the reservoir for maintaining Chlorella with a system of light-emitting diodes and an impeller mixer

Throughout the experiment, a new portion of Chlorella suspension with cellular density no less than $50 \mathrm{M} / \mathrm{ml}$ was obtained every 48 hours. The amount of Chlorella suspension for heifers and cows was calculated using the recommendations stating that the heifers which change their diet to roughage require $300-500 \mathrm{ml}$ of Chlorella suspension per individual daily (Bogdanov, 2004). For determining the norm of feeding with Chlorella suspension, an experiment had been previously conducted on Yaroslavl breed heifers r. On the basis of this experiment, a recalculation for lactating cows was made, which determined that the norm of feeding with the Chlorella suspension per kg of dry substance of daily ration for one animal is $155 \mathrm{ml}$ (Bogdanova \& Flerova, 2016).

The heifers received Chlorella suspension in the following amount (ml/individual per days): $1-30$ th day of the experiment -550 , 31-60th - 660, 61-90th day - 730, 91-120th day - 830, which in recalculation to dry substance (g/individual per days) was: 1-30th day of the experiment -1.51 , 31-60th day -1.82 , 61-90 day -2.01 , 91120th day -2.28 . The Chlorella suspension was fed to the heifers individually using special plastic bottles. During 60 days, the lactating cows were given 2,180 ml per individual a day, which in recalculation to dry substance was $6.02 \mathrm{~g}$ per individual a day.

Chlorella suspension was given individually after morning feeding: the heifers received it throughout 120 days, the cows received it during 60 days, and over the following 30 days were kept under observation to determine the "aftereffects" of the fodder additive. On the first day of the experiment and after every 30 days, before morning feeding, blood was drawn into a vacuum test tube from the jugular vein of the control and experimental animals.

The composition and ratio of leukocytes were analyzed using Giemsa stain. The identification of leukocytes used "The Atlas of 
Blood Cells of Agricultural and Laboratory Animals” (Nikitin, 1949). Under the Mikmed-6 microscope, 200 cells were calculated on each blood smear, including lymphocytes, monocytes, neutrophils, eosinophils, basophils. The number of leukocytes was calculated using the standard method of a hemocytometer (Kondrahin, 2004). The number of erythrocytes and the amount of hemoglobin was determined using an Advia 60 automatic hematological analyzer with a Timepac box complex reagent (USA-Germany).

The activity of superoxide dismutase was determined in blood hemolysate obtained by adding $0.9 \mathrm{ml}$ of water to $0.1 \mathrm{ml}$ of blood, and centrifuged at 5,000 rotations per minute during 30 minutes. We used the spectrophotometric method based on recovering of nitrotetrazolium by superoxide radicals formed as a result of interaction between phenazinemetasulfate and recovered form (NAD). The activity of the enzyme was determined at $540 \mathrm{~nm}$ wave length and expressed in conventional units per mg of hemoglobin (Chevari et al., 1985). The catalase activity was determined in the blood serum using the spectrophotometric method after adding $0.1 \mathrm{ml}$ of homogenate to
$2 \mathrm{ml}$ of $0.03 \%$ solution of hydrogen peroxide. Instead of homogenate, $0.1 \mathrm{ml}$ of distilled water was added to a dummy tube. The reaction was stopped after $10 \mathrm{~min}$ by adding $1 \mathrm{ml}$ of $4 \%$ solution of ammonium orthomolybdate, the activity of the enzyme was expressed in IU. The staining intensity was determined at $410 \mathrm{~nm}$ wave length (Korolyuk et al., 1988).

The parameters of the studied features were calculated using statistical methods. We determined the arithmetic mean (M), and the standard error (SE). For determining the differences between the average values, we tested the statistical hypotheses using Student's t-test $(\mathrm{P}<0.05)$ after a preliminary calculation of normal distribution.

\section{Results}

Heifers. The results of the study showed that the proportion of different forms of leukocytes in the blood of heifers from the control and experimental groups was within the physiological norm throughout the experiment (Table 2).

\section{Table 2}

Proportion of different forms of leukocytes in the blood of heifers $(M \pm S E, n=15)$

\begin{tabular}{|c|c|c|c|c|c|c|c|}
\hline \multirow{3}{*}{$\begin{array}{l}\text { The period } \\
\text { of the experiment }\end{array}$} & \multirow{2}{*}{ Groups } & \multirow{2}{*}{ Basophils, \% } & \multirow{2}{*}{ Eosinophils \% } & \multicolumn{2}{|c|}{ Neutrophils, \% } & \multirow{2}{*}{ Lymphocytes, \% } & \multirow{2}{*}{ Monocytes, \% } \\
\hline & & & & Band neutrophils & with segmented nuclei & & \\
\hline & $\mathrm{Norm}^{+}$ & $0-2$ & $3-8$ & $2-5$ & $20-35$ & $40-75$ & $2-7$ \\
\hline \multirow{2}{*}{$1^{\text {st }}$ day } & control & 0 & $4.10 \pm 0.33$ & $3.10 \pm 0.11$ & $20.6 \pm 1.1$ & $68.4 \pm 0.7$ & $3.70 \pm 0.49$ \\
\hline & experimental & 0 & $4.40 \pm 0.59$ & $3.20 \pm 0.14$ & $20.6 \pm 0.4$ & $69.4 \pm 3.6$ & $3.40 \pm 0.33$ \\
\hline \multirow{2}{*}{$30^{\text {th }}$ day } & control & 0 & $4.50 \pm 0.35$ & $3.29 \pm 0.33$ & $20.5 \pm 0.7$ & $68.3 \pm 1.5$ & $2.79 \pm 0.26$ \\
\hline & experimental & 0 & $4.71 \pm 0.29$ & $3.36 \pm 0.23$ & $20.5 \pm 0.7$ & $68.2 \pm 1.6$ & $2.86 \pm 0.15$ \\
\hline \multirow{2}{*}{$60^{\text {th }}$ day } & control & 0 & $4.75 \pm 0.42$ & $3.20 \pm 0.22$ & $20.6 \pm 0.4$ & $68.2 \pm 0.4$ & $2.80 \pm 0.22$ \\
\hline & experimental & 0 & $4.91 \pm 0.54$ & $3.30 \pm 0.14$ & $20.9 \pm 0.7$ & $68.3 \pm 0.2$ & $2.90 \pm 0.21$ \\
\hline \multirow{2}{*}{$90^{\text {th }}$ day } & control & 0 & $4.46 \pm 0.23$ & $3.21 \pm 0.24$ & $20.1 \pm 0.3$ & $68.7 \pm 1.0$ & $3.21 \pm 0.39$ \\
\hline & experimental & 0 & $4.65 \pm 0.34$ & $3.64 \pm 0.23$ & $20.9 \pm 0.5$ & $68.9 \pm 0.8$ & $3.29 \pm 0.16$ \\
\hline \multirow{2}{*}{$120^{\text {th }}$ day } & control & 0 & $4.56 \pm 0.34$ & $3.28 \pm 0.39$ & $20.3 \pm 0.5$ & $69.1 \pm 0.3$ & $3.07 \pm 0.21$ \\
\hline & experimental & 0 & $4.74 \pm 0.23$ & $3.71 \pm 0.29$ & $20.7 \pm 0.4$ & $69.6 \pm 0.9$ & $3.21 \pm 0.35$ \\
\hline \multirow{2}{*}{$150^{\text {th }}$ day } & control & 0 & $4.59 \pm 0.27$ & $3.24 \pm 0.25$ & $20.6 \pm 0.5$ & $69.5 \pm 0.2$ & $3.18 \pm 0.26$ \\
\hline & experimental & 0 & $4.64 \pm 0.17$ & $3.68 \pm 0.33$ & $20.9 \pm 0.9$ & $69.6 \pm 0.7$ & $3.25 \pm 0.43$ \\
\hline
\end{tabular}

Note: * ${ }^{*} \mathrm{P}<0.05$ according to Student's t-test compared to the control; ${ }^{+}-$according to Nikitin (1949), Kondrahin (2004).

It should be mentioned that at all stages of the experiment, no basophils were found in the blood of heifers from the control and experimental groups (Table 2). The heifers of the experimental group were observed on the 90th day and before the end of the experiment to have some increase in the relative number of band neutrophils compared to the control values (Table 2).

Table 3

Hematological parameters of Yaroslavl heifers $(\mathrm{M} \pm \mathrm{SE}, \mathrm{n}=15)$

\begin{tabular}{clccc}
\hline $\begin{array}{c}\text { Period } \\
\text { of the } \\
\text { experiment }\end{array}$ & \multicolumn{1}{c}{ Groups } & $\begin{array}{c}\text { Erythrocytes, } \\
10^{12} / 1\end{array}$ & $\begin{array}{c}\text { Hemoglobin, } \\
\text { rgl }\end{array}$ & $\begin{array}{c}\text { Leukocytes, } \\
10^{9} / 1\end{array}$ \\
\cline { 2 - 5 }${ }^{+}$ & $5.0-7.5$ & $99-129$ & $4.5-12.0$ \\
\hline \multirow{2}{*}{$1^{\text {st }}$ day } & control & $5.74 \pm 0.24$ & $109.2 \pm 5.3$ & $6.87 \pm 0.23$ \\
& experimental & $5.72 \pm 0.29$ & $110.0 \pm 5.0$ & $7.16 \pm 0.39$ \\
\multirow{2}{*}{$30^{\text {th }}$ day } & control & $5.70 \pm 0.21$ & $105.2 \pm 2.2$ & $8.28 \pm 0.41$ \\
& experimental & $5.82 \pm 0.56$ & $109.8 \pm 6.4$ & $8.67 \pm 0.51$ \\
$60^{\text {th }}$ day & control & $5.76 \pm 0.16$ & $109.0 \pm 3.0$ & $9.57 \pm 0.21$ \\
& experimental & $5.88 \pm 0.22$ & $117.0 \pm 2.0^{*}$ & $10.24 \pm 0.49$ \\
$90^{\text {th }}$ day & control & $5.91 \pm 0.21$ & $109.8 \pm 3.9$ & $10.30 \pm 0.43$ \\
& experimental & $6.38 \pm 0.19^{*}$ & $114.2 \pm 2.9$ & $11.01 \pm 0.38$ \\
$120^{\text {th }}$ day & control & $5.93 \pm 0.27$ & $108.8 \pm 3.8$ & $10.50 \pm 0.26$ \\
& experimental & $6.46 \pm 0.25^{*}$ & $113.5 \pm 4.1$ & $10.36 \pm 0.06$ \\
$150^{\text {th }}$ day & control & $5.98 \pm 0.21$ & $110.6 \pm 2.7$ & $10.23 \pm 0.43$ \\
& experimental & $6.41 \pm 0.23^{*}$ & $114.2 \pm 2.0$ & $10.45 \pm 0.18$ \\
\hline
\end{tabular}

Note: ${ }^{*}-\mathrm{P}<0.05$ according to t-criterion compared to the control; ${ }^{+}-$ according Nikitin (1949), Kondrahin (2004).

During the study, we observed a statistically insignificant increase in the total number of leukocytes within the physiological norm in both groups of animals (Table 3). The number of erythrocytes among heifers of the experimental group was a little higher on the 30th and 60th days of feeding with Chlorella suspension compared to this parameter in the blood of animals from the control group. Then, this parameter reliably increased on the 90th and 120th days of the experiment in comparison to the same parameters for the control by $7.95 \%$ and $8.93 \%$ respect- tively, and this excess remained on the 30th day after the feeding with Chlorella suspension was over and equaled $7.20 \%$ (Table 3). At the same time, the hemoglobin content of animals from the experimental group exceeded this parameter in the control group, and by the 60th day, the difference between the content of hemoglobin in blood of animals from the control and experimental group was $7.30 \%$ and was statistically significant (Table 3). On the 90th and 120th days of the experiment, we observed some increase in the content of hemoglobin in blood of animals from experimental group compared to the control, and this tendency remained on the 30th day after the feeding with the suspension additive was over (Table 3).

Table 4

Activity of the enzymes of anti-oxidant system of Yaroslavl heifers at the stages of study $(\mathrm{M} \pm \mathrm{SE}, \mathrm{n}=15)$

\begin{tabular}{clcc}
\hline \multirow{2}{*}{$\begin{array}{c}\text { Period of the } \\
\text { experiment }\end{array}$} & \multicolumn{1}{c}{ Groups } & $\begin{array}{c}\text { SOD, conv.units/mg } \\
\text { of hemoglobin }\end{array}$ & CAT, IU \\
\cline { 2 - 4 } & \multicolumn{1}{c}{ Norm $^{+}$} & $1.0-7.5$ & $20-60$ \\
\hline \multirow{2}{*}{$1^{\text {st }}$ day } & control & $4.39 \pm 0.33$ & $39.40 \pm 0.30$ \\
& experimental & $4.97 \pm 0.14$ & $42.00 \pm 2.91$ \\
\multirow{2}{*}{$30^{\text {th }}$ day } & control & $4.13 \pm 0.58$ & $34.80 \pm 1.52$ \\
& experimental & $4.70 \pm 0.76$ & $36.00 \pm 2.72$ \\
\multirow{2}{*}{$60^{\text {th }}$ day } & control & $4.86 \pm 0.75$ & $32.90 \pm 1.25$ \\
\multirow{2}{*}{$90^{\text {th }}$ day } & experimental & $5.22 \pm 0.37$ & $36.00 \pm 0.50^{*}$ \\
\multirow{2}{*}{$120^{\text {th }}$ day } & control & $4.68 \pm 0.19$ & $35.78 \pm 2.78$ \\
\multirow{2}{*}{$150^{\text {th }}$ day } & conperimental & $5.06 \pm 0.28$ & $40.20 \pm 2.06^{*}$ \\
& experimental & $4.74 \pm 0.24$ & $35.38 \pm 1.44$ \\
& control & $5.10 \pm 0.19$ & $39.40 \pm 1.71^{*}$ \\
\hline \multirow{2}{*}{$*$} & experimental & $4.81 \pm 0.28$ & $36.18 \pm 1.74$ \\
\end{tabular}

Note: $*-\mathrm{P}<0.05$ according to t-criterion compared to the control, SOD superoxide dismutase, CAT - catalase; ${ }^{+}$- according to Kondrahin (2004).

At the beginning of the experiment, the heifers of the experimenttal group were observed to have an increase in the activity of catalase 
in the blood serum; on 60th, 90th and 120th days it was significantly higher compared to the control, equaling $9.4 \%, 12.4 \%$ and $11.4 \%$ respectively ( $\mathrm{P}<0.05)$, on the 30th day after the end of feeding with Chlorella suspension, this increase remained statistically significant, equaling $8.9 \%$ (Table 4). It should be mentioned that throughout the experiment the activity of superoxide dismutase in the experimental group was a little higher than in the control group. However no statistically reliable increase in this parameter compared to the control was observed (Table 4).

Lactating cows. The proportion of separate forms of leukocytes in the blood of lactating cows of the control and experimental groups was also within the physiological norm (Table 5). No basophils were found in the blood of animals from either group. By the 30th day of the experiment, the relative number of band and neutrophils with segmented nuclei in the blood of lactating cows of the experimental group had slightly increased compared to the similar parameters of the control, and this tendency remained throughout the period of feeding with the additive.

It should be mentioned that on the 60th day, we observed a statistically significant increase in the number of eosinophils in the blood of lactating cows of the experimental group by $2.2 \%$ compared to the control value. On the 90th day, the number of monocytes in the blood of cows from the experimental group increased by $2 \%$ compared to the control (Table 4). Over the experiment, the hematological parameters of blood of lactating cows from the control and experimental groups were within the physiological norm (Table 5).

Table 5

The proportion of separate forms of leukocytes of lactating cows of Yaroslavl breed $(M \pm S E, n=15)$

\begin{tabular}{|c|c|c|c|c|c|c|c|}
\hline \multirow{3}{*}{$\begin{array}{l}\text { Period of the } \\
\text { experiment }\end{array}$} & \multirow{2}{*}{ Groups } & \multirow{2}{*}{ Basophils, \% } & \multirow{2}{*}{ Eosinophils \% } & \multicolumn{2}{|c|}{ Neutrophils, \% } & \multirow{2}{*}{ Lymphocytes, \% } & \multirow{2}{*}{ Monocytes, \% } \\
\hline & & & & band neutrophils & with segmented nuclei & & \\
\hline & Norm $^{+}$ & $0-2$ & $3-8$ & $2-5$ & $20-35$ & $40-75$ & $2-7$ \\
\hline \multirow{2}{*}{$1^{\text {st }}$ day } & control & 0 & $4.00 \pm 1.16$ & $4.93 \pm 0.70$ & $20.6 \pm 1.4$ & $73.6 \pm 2.5$ & $2.57 \pm 0.86$ \\
\hline & experimental & 0 & $3.71 \pm 2.30$ & $4.79 \pm 1.26$ & $20.1 \pm 1.3$ & $75.0 \pm 3.1$ & $2.86 \pm 1.70$ \\
\hline \multirow{2}{*}{$30^{\text {th }}$ day } & control & 0 & $3.92 \pm 0.88$ & $4.43 \pm 0.69$ & $20.6 \pm 1.3$ & $69.4 \pm 2.7$ & $2.07 \pm 0.25$ \\
\hline & experimental & 0 & $4.00 \pm 0.54$ & $4.64 \pm 1.43$ & $22.0 \pm 1.2$ & $73.7 \pm 3.1$ & $3.14 \pm 0.85$ \\
\hline \multirow{2}{*}{$60^{\text {th }}$ day } & control & 0 & $4.29 \pm 0.75$ & $3.88 \pm 1.88$ & $20.6 \pm 1.8$ & $68.5 \pm 2.6$ & $3.23 \pm 1.05$ \\
\hline & experimental & 0 & $6.50 \pm 0.51^{*}$ & $4.14 \pm 1.79$ & $20.6 \pm 1.4$ & $70.9 \pm 3.6$ & $3.21 \pm 1.24$ \\
\hline \multirow{2}{*}{$90^{\text {th }}$ day } & control & 0 & $6.64 \pm 1.66$ & $4.00 \pm 2.08$ & $20.1 \pm 1.9$ & $63.0 \pm 3.8$ & $2.36 \pm 0.84$ \\
\hline & experimental & 0 & $6.71 \pm 2.08$ & $4.43 \pm 1.87$ & $21.9 \pm 1.9$ & $59.9 \pm 4.4$ & $4.36 \pm 1.19 *$ \\
\hline
\end{tabular}

Note: $*_{-} \mathrm{P}<0.05$ according to t-criterion compared to the control; ${ }^{+}$- according to Nikitin (1949), Kondrahin (2004).

On the 30th day of the experiment, the number of erythrocytes of animals from the experimental group statistically significantly increased by $15.3 \%$ compared to the parameters of the control group, the observed tendency remained on the 60th and 90th days of the experiment and the excess of this parameter in the blood of animals from the experimental group was 5.1 and $4.5 \%$ respectively. At the same time, against the background of increase in the number of erythrocytes, an increase occurred in the content of hemoglobin in the blood of animals from the experimental group, which by the end of the 60th day equaled $8.4 \%(\mathrm{P}<0.05)$, this excess remained on the 90th day of the experiment, equaling $6.8 \%$. On the 30th and 60th days of the experiment, the total number of leukocytes in the blood of lactating cows of the experimental group was slightly higher than it was in the blood of animals from the control group (Table 6).

Table 6

Hematological parameters of lactating cows of Yaroslavl breed $(\mathrm{M} \pm \mathrm{m})$

\begin{tabular}{clccc}
\hline \multirow{2}{*}{\begin{tabular}{c} 
Period $\begin{array}{c}\text { of the } \\
\text { experiment }\end{array}$ \\
\cline { 2 - 5 }
\end{tabular}} & $\begin{array}{c}\text { Groups, } \mathrm{n}= \\
15\end{array}$ & \multicolumn{1}{c}{$\begin{array}{c}\text { Erythrocytes, } \\
10^{12} / \mathrm{l}\end{array}$} & $\begin{array}{c}\text { Hemoglobin, } \\
\mathrm{g} / \mathrm{l}\end{array}$ & $\begin{array}{c}\text { Leukocytes, } \\
10^{9} /\end{array}$ \\
\hline \multirow{2}{*}{$1^{\text {st }}$ day } & \multicolumn{1}{c}{$5.0-7.5$} & $99-129$ & $4.5-12.0$ \\
& control & $5.00 \pm 0.23$ & $99.2 \pm 4.3$ & $8.90 \pm 1.31$ \\
& experimental & $5.00 \pm 0.34$ & $100.0 \pm 5.0$ & $9.00 \pm 1.49$ \\
\multirow{2}{*}{$30^{\text {th }}$ day } & control & $5.11 \pm 0.13$ & $99.0 \pm 1.6$ & $8.65 \pm 0.50$ \\
& experimental & $5.89 \pm 0.42^{\text {th }}$ day & $102.0 \pm 5.0$ & $9.02 \pm 0.58$ \\
& control & $5.06 \pm 0.16$ & $96.9 \pm 2.8$ & $7.72 \pm 0.83$ \\
& experimental & $5.32 \pm 0.19^{*}$ & $105.0 \pm 3.0^{*}$ & $7.90 \pm 0.80$ \\
$90^{\text {th }}$ day & control & $5.31 \pm 0.12$ & $103.0 \pm 2.0$ & $7.98 \pm 0.25$ \\
& experimental & $5.55 \pm 0.22$ & $110.0 \pm 3.0^{*}$ & $7.97 \pm 0.20$ \\
\hline
\end{tabular}

Note: * $-\mathrm{P}<0.05$ according to t-criterion compared to the control; ${ }^{+}-$according to Kondrahin (2004).

Throughout the experiment, the parameters of activity of catalase and superoxide dismutase among animals of the control and experimental groups were within the physiological norm. It should be mentioned that the parameters of the activity of superoxide dismutase and the activity of catalase of cows which received the Chlorella additive, were slightly higher than those of animals from the control group throughout the experiment (Table 7).

\section{Discussion}

Analysis of data from the literature showed that no experiment with usage of suspension of Chlorella stimulated by electrostatic field as a fodder additive for animals had been conducted before. However, there are detailed descriptions of the impact of the microalgae cultivated using other technologies, on the organism of both laboratory and agricultural animals. Use of concentration of Chlorella had a physiological and pharmaceutical effect on the organism of mice and rats, manifesting a stimulating effect on the lipid metabolism, immune modulating and antibacterial activity of the organism of laboratory animals (Hasegawa et al., 1997; Shibata et al., 2001). Also, this microalgae showed strong antioxidant properties which prevent the effect of oxidative stress, when it is used in treating mice with naphthalene intoxication, and also rats suffering from diabetic disorders and oxidative stress under the impact of cadmium (Shibata et al., 2003; Vijayavel et al., 2007, Kim et al., 2009). It has been demonstrated that Chlorella participates in modeling immune reactions in the organism of animals and increases the activity of hematopoietic cells which prevent the development of tumours (Tanaka et al., 1984; Tanaka et al., 1990; Ramos, 2010).

Table 7

Activity of enzymes of anti-oxidant system of lactating cows of the Yaroslavl breed at the stages of the study $(M \pm S E, n=15)$

\begin{tabular}{clcr}
\hline Period of the & \multicolumn{1}{c}{ Group } & SOD, unit /mg of hemoglobin & CAT, $\mu \mathrm{mol} / /$ \\
\cline { 2 - 4 } experiment & \multicolumn{1}{c}{ Norm $^{+}$} & $1.0-7.5$ & $20-60$ \\
\hline \multirow{2}{*}{$1^{\text {st }}$ day } & control & $3.59 \pm 0.38$ & $27.33 \pm 2.39$ \\
& experimental & $3.64 \pm 0.33$ & $27.17 \pm 3.59$ \\
\multirow{3}{*}{ 30st day } & control & $3.45 \pm 0.96$ & $31.69 \pm 2.80$ \\
& experimental & $4.15 \pm 1.01$ & $32.12 \pm 4.48$ \\
\multirow{2}{*}{$60^{\text {th }}$ day } & control & $2.36 \pm 0.50$ & $33.67 \pm 5.39$ \\
& experimental & $2.39 \pm 0.37$ & $34.76 \pm 8.35$ \\
$90^{\text {th }}$ day & control & $2.48 \pm 0.24$ & $29.45 \pm 0.23$ \\
& experimental & $2.67 \pm 0.37$ & $29.57 \pm 0.29$ \\
\hline
\end{tabular}

Note: $*-\mathrm{P}<0.05$ according to the t-criterion in comparison with the control; SOD - superoxide dismutase, CAT - catalase; ${ }^{+}$- according to Kondrahin (2004).

Feeding different age groups of pigs and cattle with Chlorella suspension contributed to increase in hemoglobin in the blood, increase in the number of erythrocytes and some forms of leukocytes. Using Chlorella suspension as a fodder additive in diets of different age groups of pigs caused increase in the number of monocytes and decrease in the level of cholesterol in blood serum, and using the microalgae in the diet of young cattle caused normalization of the physiological parameters of the animals' blood serum, strengthened enzyme activity and increased content of $\gamma$ - globuline fraction of protein (Kotrbáček et al., 1995; Doucha et al., 2009; Yan et al., 2012; Oshurkova et al., 2015; Panov et al., 2016; Lamminen et al., 2017). 
The results of our experiments coincide with the data provided by other researchers and demonstrate that the biochemical composition and hematological parameters of the blood of heifers and lactating cows which received an additive of suspension of Chlorella cultivated in a closed bioreactor under stimulation by electrostatic field, in the amount of $155 \mathrm{ml}$ per a $\mathrm{kg}$ of dry substance of the animals' diet were within the physiological norm regardless of the duration of feeding. We demonstrated the Chlorella suspension's stimulating effect on erythro- and leukopoiesis of different age groups of cattle, and also the shift of leukogram towards increase in the relative number of separate forms of leukocytes and increase in the hemoglobin count. Increase in hemoglobin when there is increase in the number of erythrocytes within the physiological norm according to the data on blood parameters of heifers and lactating cows of the experimental groups indicates the increase in the speed of redox reactions, contributes to increase in the oxygen capacity and provides the tissues with oxygen, thus causing strengthening in metabolic processes in the organism of animals (Nadarinskaya, 2004; Krisanov et al., 2014). At all stages of the experiment, we found no basophils in the blood of heifers and lactating cows of the experimental groups, which indicates absence of allergic reactions in the organism, such as allergic reactions to fodder elements, including Chlorella suspension (Kondrahin, 2004; Karasuyama et. al., 2011).

The animals which received the addition of Chlorella were observed to have an increase in parameters of catalase and superoxide dismutase throughout the experiment. We demonstrated that the increase in the activity of superoxide dismutase was followed by activation of catalase activity parameters both among heifers and cows of the experimental groups, which indicates absence of disbarlance in the antioxidant system (Nisticò et al., 1992). We determined that feeding different age groups of cattle with Chlorella additive stimulates the system of antioxidant protection of the organism of animals, thus increases the level of non-specific resistance (Kondrahin, 2004). As we know, the overall changes in the biochemical and hematological parameters analyzed in the study within the physiological norm also indicate the increase in non-specific immunity of animals (Krapivina et al., 2011). It should be mentioned that regardless of the age of animals which receivied the Chlorella additive, the organism's response occurred on the 30th day of the experiment, and also the "aftereffect" was observed for a period of 30 days after the feeding with the additive was stopped.

\section{Conclusion}

Therefore, we demonstrated the usefulness of including the suspension of Chlorella cultivated using the intensive technology using an electrostatic field, with cellular density of no less than $50 \mathrm{M}$ per a ml in a dosage of $155 \mathrm{ml}$ per $\mathrm{kg}$ of dry substance of the diet, in feeding different age groups of cattle, for it has a complex effect on increase in the biochemical, hematological and morphological blood parameters, strengthening metabolic processes and increasing the non-specific immunity of animals, which in its turn contributes to the formation of the potential for increase in productive parameters and maintenance of cattle. Therefore, we demonstrated that the suspension of Chlorella cultivated with intensive technology using an electrostatic field, with cellular density of no less than $50 \mathrm{~m}$ per a ml is useful in feeding cattle of different age groups in a dosage of $155 \mathrm{ml}$ per $\mathrm{kg}$ of dry substance of the diet.

\section{References}

Aliahmat, N. S., Noor, M. R. M., Yusof, W. J. W., Makpol, S., Ngah, W. Z. W., \& Yusof, Y. A. M. (2012). Antioxidant enzyme activity and malondialdehyde levels can be modulated by Piper betle, tocotrienol rich fraction and Chlorella vulgaris in aging C57BL/6 mice. Clinics, 67(12), 1447-1454.

Becker, E. W. (2007). Micro-algae as a source of protein. Biotechnology Advances, 25(2), 207-210.

Bishop, W. M., \& Zubeck, H. M. (2012). Evaluation of microalgae for use as nutraceuticals and nutritional supplements. Journal of Nutrition and Food Sciences, 2(5), 1-6.
Bogdanov, N. I. (2004). Ispol'zovanie chlorelly v racione sel'skohozjajstvennyh zhivotnyh [Use of Chlorella in the diet of farm animals]. Rossijskaja Sel'skohozjajstvennaja Nauka, 1, 34-35 (in Russian).

Bogdanova, A. A., \& Flerova, E. A. (2016). Vlijanie dobavki chlorelly na fiziologo-biohimicheskie i produktivnye pokazateli u telochek [Effect of chlorella on physiological, biochemical parameters and productive traits in heifers]. Problemy Biologii Produktivnyh Zhivotnyh, 2, 66-75 (in Russian).

Borowitzka, M. A. (1999). Commercial production of microalgae: Ponds, tanks, tubes and fermenters. Journal of Biotechnology, 70(1-3), 313-321.

Carvalho, A. P., Meireles, L. A., \& Malcata, F. X. (2006). Microalgal reactors: A review of enclosed system designs and performances. Biotechnology Progress, 22(6), 1490-1506.

Chevari, S., CHaba, I., \& Sekej, J. (1985). Rol' superoksiddismutazy v okislitel'nyh processah kletki i metod opredeleniya ee v biologicheskih materialah [The role of superoxide dismutase in the oxidative processes of the cell and the method of its determination in biological materials]. Laboratornoe Delo, 11, 678-680.

Christaki, E., Florou-Paneri, P., \& Bonos, E. (2011). Microalgae: A novel ingredient in nutrition. International Journal of Food Sciences and Nutrition, 62(8), 794-799.

Costa, D. F. A., Quigley, S. P., Isherwood, P., McLennan, S. R., \& Poppi, D. P. (2016). Supplementation of cattle fed tropical grasses with microalgae increases microbial protein production and average daily gain. Journal of Animal Science, 94(5), 2047-2058.

Del Campo, J. A., García-González, M., \& Guerrero, M. G. (2007). Outdoor cultivation of microalgae for carotenoid production: Current state and perspectives. Applied Microbiology and Biotechnology, 74(6), 1163-1174.

Doucha, J., Lívanský, K., Kotrbáček, V., \& Zachleder, V. (2009). Production of Chlorella biomass enriched by selenium and its use in animal nutrition: A review. Applied Microbiology and Biotechnology, 83(6), 1001-1008.

Flerova, E., \& Bogdanova, A. (2014). The features of biochemical indices of strain Chlorella vulgaris IGF No. C-111, grown in closed system. The Journal of Microbiology, Biotechnology and Food Sciences, 3, 311.

Guccione, A., Biondi, N., Sampietro, G., Rodolfi, L., Bassi, N., \& Tredici, M. R. (2014). Chlorella for protein and biofuels: From strain selection to outdoor cultivation in a Green Wall Panel photobioreactor. Biotechnology for Biofuels, 7(1), 84.

Hasegawa, T., Kimura, Y., Hiromatsu, K., Kobayashi, N., Yamada, A., Makino, M., Okuda, M., Sano, T., Nomoto, K., \& Yoshikai, Y. (1997). Effect of hot water extract of Chlorella vulgaris on cytokine expression patterns in mice with murine acquired immunodeficiency syndrome after infection with Listeria monocytogenes. Immunopharmacology, 35(3), 273-282.

Huo, S., Wang, Z., Zhu, S., Zhou, W., Dong, R., \& Yuan, Z. (2012). Cultivation of Chlorella zofingiensis in bench-scale outdoor ponds by regulation of $\mathrm{pH}$ using dairy wastewater in winter, South China. Bioresource Technology, 121, 76-82.

Karasuyama, H., Obata, K., Wada, T., Tsujimura, Y., \& Mukai, K. (2011). Newly appreciated roles for basophils in allergy and protective immunity. Allergy, 66(9), 1133-1141.

Kim, Y. J., Jeong, S., Kwon, S., \& Kim, M. K. (2009). Effect of Chlorella vulgaris intake on antioxidative capacity in rats oxidatively stressed with dietary cadmium. Food Science and Biotechnology, 18(5), 1055-1062.

Kondrahin, I. P. (2004). Metody veterinarnoj i klinicheskoj laboratornoj diagnostiki [Methods of veterinary and clinical laboratory diagnostics]. KolosS, Moscow (in Russian).

Korolyuk, M. A., Ivanova, L. K., Majorova, I. G., \& Tokareva, V. A. (1988). Metod opredeleniya aktivnosti katalazy [Method for determination of catalase activity]. Klinicheskaya Laboratornaya Diagnostika, 4, 44-47.

Kotrbacek, V., Filka, J., Ingr, I., \& Dvorak, J. (1995). The effect of application of the alga Chlorella vulgaris on the occurrence of the pork defects. Zivocisna Vyroba, 11(40), 519-522.

Krapivina, E. V., Ivanov, D. V., \& Lifanova, J. V. (2011). Vlijanie raznyh doz probiotika "Tetralaktobakterin” na morfobiohimicheskie harakteristiki gomeostaza teljat [Influence of different doses of the probiotic "Tetralactobacterin" on the morphobiochemical characteristics of calves' homeostasis]. Vestnik Orlovskogo Gosudarstvennogo Agrarnogo Universiteta, 31(4), 41-44 (in Russian).

Krisanov, A. F., Gorbacheva, N. N., \& Demin, V. V. (2014). Gematologicheskie pokazateli korov pri kruglogodovom odnotipnom kormlenii. [Hematological indices of cows with year-round feeding of the same type]. Vestnik Ul'janovskoj GSHA, 27, 107-109 (in Russian).

Lamminen, M., Halmemies-Beauchet-Filleau, A., Kokkonen, T., Simpura, I., Jaakkola, S., \& Vanhatalo, A. (2017). Comparison of microalgae and rapeseed meal as supplementary protein in the grass silage based nutrition of dairy cows. Animal Feed Science and Technology, 234, 295-311.

Lee, S., Kang, H., Lee, H., Kang, M., \& Park, Y. (2010). Six-week supplementation with Chlorella has favorable impact on antioxidant status in Korean male smokers. Nutrition, 26(2), 175-183. 
Lee, Y. K. (2001). Microalgal mass culture systems and methods: Their limitation and potential. Journal of Applied Phycology, 13(4), 307-315.

Lum, K. K., Kim, J., \& Lei, X. G. (2013). Dual potential of microalgae as a sustainable biofuel feedstock and animal feed. Journal of Animal Science and Biotechnology, 4(1), 53.

Makartsev, N. G. (2012). Kormlenie sel'skohozjajstvennyh zhivotnyh [Feeding of farm animals]. Noosfera, Kaluga (in Russian).

Nadarinskaya, M. A. (2004). Vlijanie razlichnyh urovnej selena na produktivnost' i gematologicheskie pokazateli korov s udoem 6-7 tys. kg za laktaciju [The effect of various levels of selenium on the productivity and haematological parameters of cows with milk yield of 6-7 thousand $\mathrm{kg}$ for lactation]. Zhivotnovodstvo, 8, 6-9 (in Russian).

Nikitin, V. N. (1949). Atlas kletok krovi sel'skohozjajstvennyh i laboratornyh zhivotnyh [Atlas of blood cells of agricultural and laboratory animals]. GISHL, Kharkov (in Russian).

Nisticò, G., Ciriolo, M. R., Fiskin, K., Iannone, M., de Martino, A., \& Rotilio, G. (1992). NGF restores decrease in catalase activity and increases superoxide dismutase and glutathione peroxidase activity in the brain of aged rats. Free Radical Biology and Medicine, 12(3), 177-181.

Ogbonna, J. C., Masui, H., \& Tanaka, H. (1997). Sequential heterotrophic/autotrophic cultivation - an efficient method of producing Chlorella biomass for health food and animal feed. Joumal of Applied Phycology, 9(4), 359-366.

Oshurkova, Y. L., Fomina, L. L., Mekhanikova, M. V., \& Soboleva, Y. N. (2015). Vlijanie kormovoj dobavki Chlorella na nekotorye pokazateli krovi teljat [Influence of fodder supplement of Chlorella on some parameters of calves' blood]. Molochnohozjajstvennyj Vestnik, 19, 47-52 (in Russian).

Panahi, Y., Darvishi, B., Jowzi, N., Beiraghdar, F., \& Sahebkar, A. (2016). Chlorella vulgaris: A multifunctional dietary supplement with diverse medicinal properties. Current Pharmaceutical Design, 22(2), 164-173.

Panov, D. K., Patieva, A. M., \& Koshchaev, A. G. (2016). Nekotorye biochipmicheskie pokazateli krovi molodnyaka krupnogo rogatogo skota pri vypojke suspenzii mikrovodorosli [Some biochemical indicators of the blood of young cattle during the digestion of a suspension of microalgae]. International Research Journal, 17, e85 (in Russian).

Pulz, O., \& Gross, W. (2004). Valuable products from biotechnology of microalgae. Applied Microbiology and Biotechnology, 65(6), 635-648.

Ramos, A. L., Torello, C. O., \& Queiroz, M. L. (2010). Chlorella vulgaris modulates immunomyelopoietic activity and enhances the resistance of tumor-bearing mice. Nutrition and Cancer, 62(8), 1170-1180.
Shibata, S., Natori, Y., Nishihara, T., Tomisaka, K., Matsumoto, K., Sansawa, H., \& Nguyen, V. C. (2003). Antioxidant and anti-cataract effects of Chlorella on rats with streptozotocin-induced diabetes. Journal of Nutritional Science and Vitaminology, 49(5), 334-339.

Shibata, S., Oda, K., Onodera-Masuoka, N., Matsubara, S., Kikuchi-Hayakawa, H., Ishikawa, F., Iwabuchi, A., \& Sansawa, H. (2001). Hypocholesterolemic effect of indigestible fraction of Chlorella regularis in cholesterolfed rats. Journal of Nutritional Science and Vitaminology, 47(6), 373-377.

Shmigel', V. V., Fljorova, E. A., Bogdanova, A. A., \& Suhovskij, N. A. (2015). Ustanovka dlja vyrashhivanija chlorelly [Installation for cultivation of Chlorella], Patent RF, No 2562867 (in Russian).

Shmigel', V. V., Fljorova, E. A., Bogdanova, A. A., \& Suhovskij, N. A. (2015). Sposob vyrashhivanija chlorelly [Way of cultivation of Chlorella]. Patent RF, No 2558300 (in Russian).

Spolaore, P., Joannis-Cassan, C., Duran, E., \& Isambert, A. (2006). Commercial applications of microalgae. Journal of Bioscience and Bioengineering, 101(2), 87-96.

Tanaka, K., Konishi, F., Himeno, K., Taniguchi, K., \& Nomoto, K. (1984). Augmentation of antitumor resistance by a strain of unicellular green algae, Chlorella vulgaris. Cancer Immunology Immunotherapy, 17(2), 90-94.

Tanaka, K., Tomita, Y., Tsuruta, M., Konishi, F., Okuda, M., Himeno, K., \& Nomoto, K. (1990). Oral administration of Chlorella vulgaris augments concomitant antitumor immunity. Immunopharmacology and Immunotoxicology, 12(2), 277-291.

Vijayavel, K., Anbuselvam, C., \& Balasubramanian, M. P. (2007). Antioxidant effect of the marine algae Chlorella vulgaris against naphthalene-induced oxidative stress in the albino rats. Molecular and Cellular Biochemistry, 303(1-2), 39-44.

Viktorov, P. I., \& Menkin, V. K. (1991). Metodika i organizacija zootehnicheskih opytov [Methods and organization of zootechnical experiments]. Agropromizdat, Moscow (in Russian).

Yan, L., Lim, S. U., \& Kim, I. H. (2012). Effect of fermented Chlorella supplementation on growth performance, nutrient digestibility, blood characteristics, fecal microbial and fecal noxious gas content in growing pigs. AsianAustralasian Journal of Animal Sciences, 25(12), 1742.

Zheng, L., Oh, S. T., Jeon, J. Y., Moon, B. H., Kwon, H. S., Lim, S. U., \& Kang, C. W. (2012). The dietary effects of fermented Chlorella vulgaris $\left(\mathrm{CBT}^{\circledR}\right)$ on production performance, liver lipids and intestinal microflora in laying hens. Asian-Australasian Journal of Animal Sciences, 25(2), 261-266. 